Article

\title{
Responsible Tourism-Integrating Families with Disabled Children in Tourist Destinations
}

\author{
Alina Simona Tecău ${ }^{1}$, Gabriel Brătucu ${ }^{1}$, Bianca Tescașiu ${ }^{1}$, Ioana Bianca Chițu ${ }^{1, *}$, \\ Cristinel Petrișor Constantin ${ }^{1}$ (D) and Diana Foris ${ }^{2}$ (D) \\ 1 Faculty of Economic Sciences and Business Administration, Transylvania University of Braşov, str. Colina \\ Universitatii, nr. 1, Building A, 500068 Braşov, Romania \\ 2 Faculty of Food and Tourism, Transylvania University of Braşov, str. Castelului, nr.148, \\ 500014 Braşov, Romania \\ * Correspondence: ioana.chitu@unitbv.ro
}

Received: 26 June 2019; Accepted: 7 August 2019; Published: 15 August 2019

check for updates

\begin{abstract}
This article addresses issues regarding the intention of responsible tourism to increase the accessibility of tourist destinations for children with disabilities and their families. The main objective of this research is to identify the barriers that families with disabled children confront during their touristic experiences and to find ways to diminish these barriers. In this respect, qualitative marketing research based on the focus group method was conducted. The research results revealed that the most important barriers faced by such families are attitude barriers, followed by physical barriers and a lack of information. Starting from these results, we proposed the higher involvement of national authorities and other stakeholders in strategies meant to decrease or remove the barriers faced by people with disabilities and their attendants in order to develop responsible tourism. Such strategies could firstly involve the development of a primary school curriculum by including educational programs that are meant to avoid attitude barriers. Secondly, other stakeholders could use new emerging technologies, such as virtual reality, to offer tourists the opportunity to experience some tourism products and places before they travel.
\end{abstract}

Keywords: responsible tourism; families with disabled children; tourist destinations; tourism stakeholders; virtual reality

\section{Introduction}

According to the Cape Town Declaration, responsible tourism means "making better places for people to live in and better places for people to visit" and involves responsibilities for all the stakeholders in the hospitality field (tour operators, hoteliers, governments, local people, tourists, etc.) towards a common goal: to make tourism more sustainable. Two of the many forms of responsible tourism recognized by the Cape Town Declaration are the provision of more enjoyable experiences for tourists and access for people with disabilities [1]. Moreover, tourism activities can contribute to the sustainable development goals set up by the United Nations in 2015, which aim to decrease and eradicate poverty, to protect the planet, and to ensure equality and prosperity. One example of action could be the integration of people with disabilities in destination sites by eliminating some barriers, such as physical and attitude barriers [2]. At the same time, tourist activities can bring many benefits to persons with disabilities such as enhancing personal development, increasing their social inclusion, and increasing their quality of life [3,4].

The preoccupation with studying tourists with special needs represents both a form of responsible tourism and also a way to help achieve the United Nations' the sustainable development goals, while the statistics regarding persons with disabilities at the beginning of 2018 reflect that more than a 
billion people- $15 \%$ of the world's population—had a form of disability [5], with at least $10 \%$ being children and $80 \%$ living in developing countries [6].

For disabled children and their families, taking part in tourism represents a challenge in an environment designed for people without disabilities [4,7]. A vacation with a child with disabilities represents a challenge for both the family, because of its complex features [8], and for the tourism stakeholders. Lately, a significant number of concerns regarding the use of the tourism industry as a tool for social integration have been noticed [9]. Identifying possibilities for the better and easier integration of these people in the tourist destinations and for diminishing barriers by adapting the accommodation facilities, the food units, the tourist attractions, and the communication tools specific to serve special needs also represents a development opportunity for companies in the tourism industry. At the same time, changing people's mentality regarding the acceptance of people with disabilities represents a challenge for the entirety of society.

Integrating people with disabilities in tourism activities has become increasingly attractive for the academic environment [10], but the link between responsible tourism and the process of integrating people with disabilities in tourism destinations still represents a challenge, as it is a topic which is seldom approached. There are, however, some studies that approach the issue of integrating people with disabilities into tourism by proposing different solutions. One of these solutions consists of using virtual reality in the communication process, since it represents a successful, already used tool in tourism but has been rarely explored for the mentioned audiences.

In this context, the scope of our research was to identify the barriers that families with disabled children confront in their tourist experiences and the possibilities to diminish these barriers. Considering the proposed scope, based on focus group research, this article intends to present opinions regarding the touristic experiences of some parents of children with disabilities on the one hand, and on the other hand, a specialist's point of view of these issues.

The main research questions were conceived by the authors in order to achieve the main objectives of the study, as follows: (Q1) What are the main barriers that families with disabled children confront in their relation with other stakeholders in tourism? (Q2) In what way could the degree of acceptance/integration of these people in society and also in tourist communities be improved? (Q3) What are the perceived benefits of using VR in helping families with disabled children to avoid physical barriers in tourism activities?

This research was carried out in Romania. The main reason for choosing Romania was the fact that during 2006-2019 in Romania, the number of people with disabilities has increased from nearly 500,000 persons to over 800,000. According to the National Authority for Persons with Disabilities, at the end of March 2019 in Romania, there were 826,197 persons with a form of disability $(3.73 \%$ of the population), and over 65,000 of these were children [11]. On the other hand, Romania represents a touristic country with great natural potential, and the understanding of the needs of people with disabilities by tourism stakeholders can lead to an increased need to ensure accessibility for people with disabilities.

Based on the obtained results, the article highlights some proposals regarding the possibilities of decreasing every type of the identified barriers, for a better integration of persons with disabilities in destination sites.

The article is structured as follows: Section 2 reviews the literature, Section 3 describes the research methodology, Section 4 presents the results and discussions, and Section 5 contains the conclusions and proposals.

\section{Literature Review}

Responsible tourism has been approached in the literature from many points of view by approaching the impact of the quality of life of residents from tourist destinations [12,13], the tourists' behavior [14] and the ways to encourage tourist to practice responsible tourism [15], the behavior of the managers from tourism units $[16,17]$, and the tourism operators' corporate social 
responsibility [18].Tourism is increasingly used as a tool for social integration [9]; however, there are only a few studies that have linked responsible tourism with integrating people with disabilities in tourism destinations. The most used concepts of inclusive tourism, accessible tourism, or even social tourism show that this topic is significantly raising the level of interest within the academic community regarding this issue.

The collaboration between different types of stakeholders in order to find solutions to raise the accessibility in tourism represents a research theme for many working papers in the field. In this context, the present and future visitors are also considered as stakeholders [19-23]. Considering the relationships and interactions as the stakeholders' causal scope [24] may represent a strategy for sustainable development of tourist destinations it becomes a necessity to develop a strategy that takes this aspect into consideration. Such a strategy could involve the accessibility of people with disabilities as far as the accessibility might become a competitive advantage in sustainable development of tourism companies, but also a challenge for them $[25,26]$. The competitive advantage may also occur through a holistic approach to understand these people's needs and through the ever-increasing social responsibility stemming from innovative management [27]. People with disabilities are also considered an attractive segment for new types of tourism-the sharing tourism (peer-to-peer accommodations), by offering a series of practical implications for hosts [28].

A family with a disabled child presents different dynamics in holidays, with both typical and distinctive costs and benefits [8]. Specialists studied the problems/barriers faced by families with disabled children in their desire to practice tourism and, also, the benefits those holidays can offer them. Many tourist destinations were found unavailable for these families for a lot of reasons like the special needs of the child or of the other members of the family, the ways of transport or the accommodation units [29]. Another studied issue is the tendency to "underestimate the beneficial effects of intrapersonal and interpersonal relationships" in the attempt to make the tourist destinations more accessible to disabled children and their families [30].

Although all the constraints, specialists studied the benefits that a holiday can bring to families with children with disabilities and the strategies adopted by these families to make the experience as enjoyable as possible for these children [31]. Benefits such as well-being, health improvement, reducing the level of loneliness and social connection were highlighted [32,33].

Eichhorn and Buhalis (2011) identify three types of barriers in tourism for people with disabilities - physical barriers, attitude barriers and the lack of information. These barriers are analyzed and researched in the literature, both separately and together [34].

Many researchers recognize that physical barriers represent a major impediment for many people with disabilities. For instance, regarding accommodation, five predictors of satisfaction for people with disabilities were identified-accessibility in rooms, in public areas, in recreation spaces, in bath and in restaurants and bars-and the conclusion was that the satisfaction experienced by these people is directly proportional to the degree of accessibility offered by the hotel $[35,36]$. A qualitative study on people with disabilities from Israel concluded, for instance, that they face challenges both because of the physical design of the hotel as well as personnel behavior, so hotel managers need to take measures to mitigate these risks [37].

Transport also represents an important component of the touristic experience, and different categories of stakeholders - both local authorities and private operators - must assure proper traveling conditions for people with disabilities. In the literature there are a lot of studies regarding the urban transportation system to meet the needs of these people [38-42] or other ways of transport, such as air transport $[43,44]$. Even though some improvements were achieved during last years, the needs of people with disabilities are still insufficiently understood; companies have to be creative not only to facilitate the access for people with disabilities, but, also, to decrease the cost of transportation for them [45]. 
The first question of this study starts from the barriers identified in the previous studies-(Q1) What are the main barriers that families with disabled children are confronting in their relation with other stakeholders from tourism?

The tourist experience undoubtedly includes non-physical components related to interaction with personnel and other visitors, and their attitude towards people with disabilities can transform this experience into an unpleasant one [46]. An educational program regarding persons with disabilities in the schools of tourism may change the students' attitude in a positive direction [47]. These tourists (people with disabilities) require a greater sensitivity from hotel personnel; therefore, hotel managers have to take measures to improve the experience [48].

People with disabilities are living very intensive tourist experiences, so in order to understand their special needs, the removal of physical and attitudinal barriers-by staff and, also, by other tourists represents a challenge [26]. The attitude of other tourists still represents a problem, as it results from a study revealing that $2 / 3$ of the respondents agreed to share a hotel with disabled persons after they have been informed verbally about this, but, after they were offered visual information, this percentage decreased, demonstrating the fact that the degree of acceptance is still low [10].

For a better and easier integration in tourism, people with disabilities need a change in the attitudes of those around them, so another research question of this study was focused on this issue-(Q2) In what way could the degree of acceptance/integration of these people in society be improved, as well as in the tourist communities?

An important aspect that resulted from different studies is the lack of marketing communication-the facilities in tourism are suffering serious gaps in communication with people with disabilities; the communication process doesn't help these people to be included in tourist facilities, it doesn't help them to step-out the barriers and it doesn't support them to take the purchasing decision $[49,50]$. In communicating with people with disabilities, information is not only a component of marketing communication, but, also, a "transmitter of experiences" [51]. New communication technologies promise to remove barriers, extend access for people with disabilities to education, commerce, employment and entertainment [52] and facilitate them an easier social and labor integration [53]. Among these technologies, virtual reality (VR) can help people to experience a new digital environment different from the present physical environment, creating a spatial presence in a certain destination [54] and it can answer to questions in the pre-purchasing process helping customers to decide [55]. For instance, VR might be used in tourism to allow a product experience before purchase, to provide emotional experience that are "lived and visitor controlled, tours of cities and buildings, landscapes, particular destinations, museums etc." [56]. More than that, for people with disabilities, VR can provide a safe and controlled environment in which they can experiment real-world situations and where they can practice skills and abilities that it can help in the real world for a better integration [57-60].

The results of several studies demonstrated that presence in a VR experience is effective in modeling people's behavior, increasing the level of preference and visitation intention [61-63].

Even the role and benefits of using VR in tourism is far from being fully investigated, specialists recognize its importance in providing a "daydream" about a touristic destination [64] and recommend more user-centric VR studies starting from clear identification and understanding of users' needs and wishes [65]. The last question of the research considers previous considerations related to VR, (Q3) What are the perceived benefits of using VR in helping families with disabled children to avoid physical barriers in tourism activities?

\section{Research Methodology}

Considering the research questions - mentioned before - and based on the literature review, the research objectives were set, as follows: (1) Evaluating the attitude barriers faced by families of children with disabilities in relation with other stakeholders from tourism (tourists, employees of transportation companies, employees of tourist units, public authorities) during the trips they carried out as tourists; (2) Identifying the main physical barriers that make the participation of persons with 
disabilities to tourists activities harder; (3) Identifying some ideas regarding possibilities of diminishing the attitude barriers for families with disabled children; (4) Finding opportunities to use VR in order to help families with disabled children to identify and to avoid physical barriers in tourism activities. To achieve the research goals, qualitative marketing research based on the focus group method was conducted. Considering the fact that this is a delicate theme, the authors appreciated that qualitative research brings advantages in achieving the established objectives [66], and also because the themes are new for Romania - a country where focusing on the needs of persons with disabilities only became important in recent years. The research sought to identify the opinions of families with disabled children and the opinions of specialists involved in their education regarding the existing facilities, the level of training, human behavior and moral attitudes of the involved stakeholders in the tourism service providing process. The data were collected from February to March 2019 from a sample of 32 persons from Transylvania, one of the most important regions of Romania. The selection of participants was based on the official list of schools from Transylvania specialized in the education of disabled children and regular schools where these children are studying. Three schools were selected, and their managers were contacted to propose which specialists should participate in the group interviews. These specialists were asked to select the parents that should participate in the research [67]. In this way four relatively homogeneous groups with 8 participants per group were formed [68].

Two of these interviews were conducted with professionals who work with disabled children in educational institutions or as itinerant psychologist (which assist children with special education needs included in mass learning with typical children in different schools from the Transylvania region). The other two groups were conducted with parents/tutors of people with disabilities-called from now on "parents".

Inside the two group categories the researchers tried to assure the involvement of some specialists with big professional achievement and also of parents of children with different disabilities, in order to assure the trustable and reliable research. The researchers targeted to assure the heterogeneity inside the 2 type of groups, so the groups consisted of as many types of specialists and parents as possible.

For the specialist groups, the selection was based on the following criteria: specialization (in order to assure the representativeness of all the specific educational services in Romania-physiotheraphy, speech therapy, psychodiagnosis, counseling and specific therapy, special psychopedagogy, social care), and experience (in order to select those specialists with a lot of experience in working with disabled children) (See Table 1).

Table 1. Categories of respondents in the qualitative research- Specialists.

\begin{tabular}{|c|c|c|}
\hline $\begin{array}{l}\text { The Respondent's } \\
\text { Position/Specialization }\end{array}$ & Code Number & $\begin{array}{l}\text { Expected Outcomes/Child Problem/Type of Problems } \\
\text { that Children Are Facing with (in the Specialists Case) }\end{array}$ \\
\hline Speech therapist & 1 & $\begin{array}{l}\text { ASD-Autistic Spectrum Disorder, Down Syndrome, } \\
\text { Severe developmental/intellectual disability, Severe } \\
\text { hearing loss, Physical disabilities }\end{array}$ \\
\hline Psychologist & 2 & $\begin{array}{l}\text { ASD—Autistic Spectrum Disorder, Down Syndrome, } \\
\text { associated disorders, physical disorders }\end{array}$ \\
\hline Speech therapist & 3 & Developmental/intellectual disability \\
\hline Special Education Teacher & 4 & $\begin{array}{l}\text { Developmental/intellectual disability(moderate/severe), } \\
\text { ASD-Autistic Spectrum Disorder, physical disabilities, } \\
\text { hearing loss }\end{array}$ \\
\hline Special Education Teacher & 5 & $\begin{array}{l}\text { ASD_Autistic Spectrum Disorder, } \\
\text { Developmental/intellectual disability, emotional problems, } \\
\text { Epilepsy }\end{array}$ \\
\hline Psychologist & 6 & $\begin{array}{l}\text { Down Syndrome, ASD-Autistic Spectrum Disorder, } \\
\text { Physical disabilities, Developmental/intellectual disability }\end{array}$ \\
\hline
\end{tabular}


Table 1. Cont.

\begin{tabular}{|c|c|c|}
\hline $\begin{array}{l}\text { The Respondent's } \\
\text { Position/Specialization }\end{array}$ & Code Number & $\begin{array}{l}\text { Expected Outcomes/Child Problem/Type of Problems } \\
\text { that Children Are Facing with (in the Specialists Case) }\end{array}$ \\
\hline Special Education Teacher & 7 & $\begin{array}{l}\text { physical/motor deficiencies, Developmental/intellectual } \\
\text { disability, ASD—Autistic Spectrum Disorder, Down } \\
\text { Syndrome, severe associated deficiencies }\end{array}$ \\
\hline Speech therapist & 8 & $\begin{array}{l}\text { Developmental/intellectual disability(moderate/severe), } \\
\text { severe associated deficiencies, Down Syndrome, } \\
\text { ASD-Autistic Spectrum Disorder, schizoid elements, } \\
\text { Epilepsy, physical disabilities }\end{array}$ \\
\hline Special Education Teacher & 9 & $\begin{array}{l}\text { Problems of adaptation, integration, cognitive, behavioral, } \\
\text { self-control, personal autonomy }\end{array}$ \\
\hline Psychologist & 10 & Developmental/intellectual disability(moderate/severe) \\
\hline Itinerant/support teacher & 11 & $\begin{array}{l}\text { ASD—Autistic Spectrum Disorder, Down Syndrome, } \\
\text { cerebral ataxia, Stargardt's disease }\end{array}$ \\
\hline Special Education Teacher & 12 & Difficulties in learning and social adaptation \\
\hline Psychologist & 13 & Difficulties in learning and social adaptation \\
\hline $\begin{array}{l}\text { Itinerant/support teacher and } \\
\text { parent of a child with Down } \\
\text { syndrome }\end{array}$ & 14 & $\begin{array}{l}\text { ASD_Autistic Spectrum Disorder(moderate/severe), } \\
\text { sensory-auditory deficiencies, motor disabilities, Spastic } \\
\text { tetraparea, Dandy Walker Syndrome }\end{array}$ \\
\hline Itinerant/support teacher & 15 & Integration issues, Developmental/intellectual disability \\
\hline Special Education Teacher & 16 & Integration issues, Developmental/intellectual disability \\
\hline
\end{tabular}

For the parent groups, the selection criteria were: the type of child's deficiency (low, medium and high deficiency), physical deficiencies (Spastic quadriplegia), associated deficiencies (ASD-Autistic Spectrum Disorder, Down syndrome, Hyperkinetic disorder); the child's age (from 6 to 18 years); the type of school that the child attends (specific education units for severe, serious and associate deficiencies and regular schools where the children with special educational needs are allowed to study on a personalized plan) (See Table 2).

Table 2. Categories of respondents in the qualitative research-Parent/Foster parent.

\begin{tabular}{lcc}
\hline $\begin{array}{c}\text { The Respondent's } \\
\text { Position/Specialization }\end{array}$ & Code Number & $\begin{array}{c}\text { Expected Outcomes/Child Problem/Type of } \\
\text { Problems that Children Are Facing with (in } \\
\text { the Specialists Case) }\end{array}$ \\
\hline Parent/Foster parent & 17 & Nonverbal autism \\
Parent/Foster parent & 18 & ASD-Autistic Spectrum Disorder \\
Parent/Foster parent & 19 & Spastic quadriplegia, Partial epilepsy \\
Parent/Foster parent & 20 & Developmental/Intellectual disability \\
Parent/Foster parent & 21 & ASD-Autistic Spectrum Disorder \\
Parent/Foster parent & 22 & ASD-Autistic Spectrum Disorder \\
Parent/Foster parent & 23 & ASD-Autistic Spectrum Disorder \\
Parent/Foster parent & 24 & Congenital microencephaly \\
Parent/Foster parent & 25 & Down syndrome \\
Parent/Foster parent & 26 & Hyperkinetic syndrome \\
Parent/Foster parent & 27 & Developmental/Intellectual disability \\
Parent/Foster parent & 28 & ASD-Autistic Spectrum Disorder \\
Parent/Foster parent & 29 & Quadriplegia, Severe developmental disability \\
Parent/Foster parent & 30 & ASD-Autistic Spectrum Disorder \\
Parent/Foster parent & 31 & Down Syndrome \\
Parent/Foster parent & 32 & Down Syndrome \\
\hline
\end{tabular}


The four interviews were conducted by a qualified moderator using two interview guides designed to assure the objectives' achievement, with common elements and specific aspects for each category of participants.

In conducting the research, the ethical guidelines were adhered to. Participants were provided with information about the context and purpose of the study. Participants were informed that their participation was voluntary, that they were free to withdraw their consent at any time [69]. Also, they provided details about how they can learn about the results of the study.

To get the emergence of the group, during the discussions the participants had the opportunity to express themselves freely, to reveal their ideas and beliefs, without any element of restrictions on interfering in the conversation, but only after the previous speaker finished his/her exposure.

The participants were encouraged to express their own point of view, as they felt, even if their opinions were different from others' opinions, considering the fact that the research goal wasn't to get a consensus, but on contrary, to find exactly what are each participant's views about the subject; it was considered to be interesting to find out when somebody has a similar opinion or a disagreement with the others. This was encouraged by assuring all the participants that there is no restriction and by specifying clearly that all the answers are equally valuable for the purpose of the research.

The discussions have started by providing information about the necessity of audio and video recording, and by obtaining their consent to use the obtained information only for research purposes without any association with their names. They were also made aware about the extent to which confidentiality can be ensured. After the introductory discussion, some information about the research purposes was provided, followed by the request for a short presentation of the participants. Besides this information, the specialists were asked to provide a short argument of their decision to work with these children with special needs and the parents/tutors were asked to give some information about their employment status.

\subsection{Attitude Barriers}

The first objective of this research consisted in finding the barriers of attitude faced by the families with disabled children in their relation with other stakeholders from tourism. In this respect we tried to find the respondents' opinions about the way that community perceives people with disabilities and families with disabled children as tourists. We started from the assumption that such a barrier involves the way in which tourists with special needs and their families are perceived by other citizens, public authorities, employees from the urban transportation system, employees from tourism, etc.

In the first interview guide-the guide for the specialists-the question "Do you consider that children you are work with have problems of social inclusion (inappropriate perception) in public spaces when they travel?" was introduced to find the way that these children have access to social inclusion. Also, they were asked to identify some situations when disabled children/their families, as tourists, had some "inappropriate treatments" from people/tourists and to try to explain the causes of these situations in order to identify the way that specialists think that disabled children are treated.

In the parents case, the researchers considered that the issue is a delicate one, so this objective was achieved by introducing in the interview guide of a request to generally describe the experiences they had when traveled - both positive and negative ones - the constraints, the limitations and the problems that they faced. By using this technique, the researchers intended to determine the measure that parents felt by their own initiative to talk about issues related to the social inclusion of their children when they are tourists. In the same time, parents were asked to specify if they felt worried about their safety or their children's safety, and to describe those situations.

By using specific techniques in the two types of interview guides, the researchers also tried to identify the stakeholders awareness (tourists, employees from the public transportation system, managers and employees from hotels, public authorities) regarding the specific needs of persons with disabilities and how stakeholders are acting in the context of having disabled children around them. 


\subsection{Physical Barriers}

To identify the physical barriers/obstacles that disabled children are confronting when they travel, the question "In your opinion, what are the main problems that families with disabled children are confronting when they travel in a touristic scope?" was introduced in the interview guide for the specialists. In an additional section of the interview guide the specialists were asked to describe their own experiences of traveling with children with disabilities as organizers of trips for these children.

In both type of the interview guides the researchers were interested to find information about this barriers, so they introduced the following questions: "Have you ever been beneficiaries of special conditions of access to institutions, touristic objectives, accommodation units, means of transport?", "What are the issues are you informing about before you travel?", "What are the security measures you consider when planning a trip?", "What safety measures do you take into consideration in order to make sure your child feels good?", "How do you find out about the accessibility conditions for different touristic goals?".

The research also focused on improving the degree of acceptance/integration in communities/ touristic groups. In order to find ways to avoid existing barriers which don't let people with disabilities travel in optimal and safe conditions, the following questions were addressed to both categories specialists and parents: "In what ways do you consider that people, especially tourists should be informed about the special needs that some children have?", "What should people know to help them accept these children?".

Furthermore, the respondents were asked to address a message to families that don't confront these types of problems to see to what extent they appreciate that an informing and awareness campaign is necessary; to whom do they consider that the message should be directed, and what would be the media they think is best suited for transmitting the message.

Also, by applying the technique of role playing, through which experts were asked to imagine that they are in the position to improve the quality of life for children with special needs and their families, so that they feel encouraged to practice several touristic activities, the researchers tried to get some proposals regarding decisions and measures that should be taken in order to identify the tourism stakeholders that should be involved in this step.

The role of VR in Tourism for Families with Disabled Children

At the end of the discussions, the concept of VR was explained to the participants and they had the possibility to test this type of technology, to have a clear image about its potential to be used by people with disabilities in tourism.

To highlight the subjects' attitudes regarding the impact that VR could have in the enhancement of touristic activity for people with disabilities, the specialists were asked to answer to the following questions: "Could VR be used to simulate various social context, so children with special needs learn to adapt to or imitate the other children behavior, so that differences may not be so obvious?", "Do you consider that VR could help parents in planning their trip?", "Do you consider that VR could help parents in travel planning?".

In the interviews with the parents, they were asked to answer to what extent do they consider that VR could help their children adapt to new situations and better understand what is going to happen (for example, they can see where they are, what they are expected to do etc.).

The four focus groups interviews were audio-recorded, transcribed, and analyzed using Content analysis [70]. The steps of this analysis included: familiarization; identifying a thematic framework; indexing; charting; mapping; interpretation. Familiarization with the data was achieved by listening to the recordings, reading the transcripts in their entirety several times, and reading the observational notes taken during the interview or immediately after the interview [71]. For clarification of some contradictory responses, some of the specialists were later contacted to provide further details. The approach to data analysis was inductive ("conventional analysis"). Content analysis was conducted in several stages [72]. Redundant information or information that was not pertinent to 
research objectives and questions has been removed. The next stage was reviewing the raw data to get a sense of the whole and identify content. At this stage, the primary and secondary topics were identified. For example, from the physical barrier theme, a secondary theme was drawn, referring to physical barriers in public transportation, because the participants have paid a great deal of attention to this issue. Then, the data was divided into categories and subcategories; it was coded and described in a concise but significant way. Each theme was analyzed in depth, the main subtopics were identified, and significant quotations were assigned to each subtopic. The next stage involved analyzing interaction data in each content area based on the interactions and discussions between participants. To increase the rigorousness and to go beyond the verbal communication analysis of the focus group participants, a micro-interlocutor analysis was conducted [73] including non-verbal behavior [74]. To determine how participants, use different words and expressions to explain their versions of experiences, events, and so on, discourse analysis was used [74]. The results obtained through previous steps for each content area were integrated. All subcategories and categories, from "manifest analysis "of content, and all subtopics and themes from "latent content analysis" [72] were grouped into "subgroups" and "groups". Finally, the results of all content areas were integrated and the whole results were reported.

Validity of the study was done using "Data triangulation" [75]. For each objective, information obtained from the parent group was compared with information obtained from the group of specialists as well as with the results of other research in the specialized literature. The results were presented in an integrated way so as to present all groups and subgroups in all content areas in a short text, in a specific manner for qualitative studies [72].

\section{Results and Discussions}

The research results are structured by considering every objective stated based on the answers to the research questions. The first question (Q1) was divided into 2 objectives (O1 and O2), namely attitude barriers and physical barriers.

(1) Evaluating the attitude barriers faced by families of children with disabilities in relation with other tourism stakeholders (tourists, employees of transportation companies, employees of tourist units, and public authorities) during the trips they carried out as tourists.

All the participants considered that neither other tourists (typical tourists) nor authorities nor the employees working in tourism are sufficiently prepared for ideal behavior regarding people with disabilities or their families, which confirms that they require greater sensitivity for interactions with these groups [48], and the need for special training for staff [47].

As was mentioned before [8], families with a disabled child sometimes have a particular distinction - some of the children with special needs, despite the fact that they have a physiognomy that doesn't show their medical disease, have an aggressive behavior or on the contrary they are too sensitive. Because of these features, other children sometimes avoid them. The pattern of this behavior is more evident when children with disabilities have other problems as well.

A major problem also revealed in other studies is interactions with staff or other tourists $[10,26,46$, 48]. Regarding the large public (the other typical tourists), the conclusions of the answers given by the sample members reveal that just a small part of the large public really knows how to behave when a family with a child with disabilities is around. It's obvious that in Romania, generally speaking, people do not behave naturally around people with disabilities. The respondents consider that the main cause of this behavior resides in the fact that Romanian people are not used to seeing people with disabilities in the public space, a conclusion that is different to the results of other studies from Northern Europe [51]. This behavior is the consequence of at least two factors: cultural factors and economic factors. In the Romanian culture, in the past, especially in rural environments, having a child with disabilities was considered to be a shameful situation, and the whole family became anti-social. In a family with a child with disabilities one of the parents—usually the mother-gives up on working, so the family income is affected (as in other countries [41,76]). In addition, an important share of the family income is spent on 
therapies or medication. In these circumstances, the family members' participation in public activities whether they are cultural or touristic activities - is significantly reduced.

"It happened to me a lot of times that parents or grandparents didn't let their child play with my child or to left the park when we arrived at the playground" (\#19), said a Down Syndrome child's mother. Another situation was described by a mother of a child with many psychic and physical disabilities: "other people looked at us like they were looking at a strange thing" (\#29). A mother of a child with multiple disabilities said: "When in a restaurant, some of the seats remained free around us. In some situations, we had to avoid public transportation or to leave the theatre". (\#21)

All the research participants agreed that families with disabled children do not feel comfortable in public spaces, and their children are avoided by the other children, in concordance with the previous studies related social models of disability [76-78]. These findings confirm the results of other research, according to which tourists' desires to share public places with disabled people on holiday are low [10]. One of the psychologists that accompanied a group of such families in a camp at the seaside declared that "Everyday there was an open space between us and the others on the beach" (\#4). When they were asked about the way that children were affected in this situation, the psychologists agreed that the most affected were the parents. "Most of the children live in their own world, they don't understand and they are not affected. The ones that are suffering are the family members." (\#2). The parents understand, see and feel; sometimes they are too exhausted to react or suffer anymore but they are striving to make the best of their children's experiences, they try to find explanations, to find excuses for people's behavior and ignorance. The findings are consistent with results of other studies [31].

Both categories of participants - parents and specialists - tried to explain this behavior by the fact that tourists do not want to interfere by such problems during their holidays. Of course, there are some exceptions. One of the participants shared a positive experience about a vacation in Romania, when she had a real support in taking care of the disabled child from a couple of tourists from the same hotel. This parent described that experience by offering details about the joy, admiration, and gratitude for the behavior of a supportive couple. Some of the other parents declared that they would feel happier if people were more emphatic and understanding. The participants agreed that improving people's attitudes regarding families with disabled children is needed, an idea that is consistent in other studies [47,77-79]. The participants considered that such an attitude change might be accomplished through adequate educational policies. Education should start from the idea of that these families have the same human rights as others, an idea highlighted by most of the specialists that are working with persons with disabilities [47,49].

The respondents considered that the authorities are not enough involved in solving the problems of the families with disabled children. Some of the specialists consider that the current rights should be improved by law and they should be better known by the society [76]; also, they consider that the way that these rights are accomplished should be a main concern of the authorities.

"People with disabilities need rights, not mercy", said one of the psychologists during the research. (\#1).

In this context, the role of the legislative package in the field was stressed, by pointing out the fact that it should be aligned to the standards from the international level, and, also the role of the public authorities-that should check out to what extent the rights provided by this law are complied with-was stressed. In opposition, some of the parents consider that these rights, when exposed in a too strong way, have a contrary effect, by making citizens angry. In this context, a declaration made by a mother with a child with multiple diseases is relevant:

"We hear a lot of times - including on mass-media - comments made by the general public or by leaders saying that In Romania only children with disabilities get support ... What about award winning children?" (\#19). "Such comments make me suffer very much" said a mother and all the other parents agreed that in Romania, the families with disabled children are disadvantaged.

One of the participants argued, in consensus with the others, that public attitudes and the authorities' attitudes can be seen by the way that their rights are sustained. According to some opinions, 
this attitude of support and protection for families with disabled children has a negative impact on their lives. Instead of fighting, they are just expecting help. One of the specialists (\#21) considers that people with disabilities and their families have gained the respect of others instead of expecting protective behavior from them. Regarding the personnel working in the tourist accommodation units or in the urban transportation companies, the respondents stressed several times, even without a direct question about this, that the employees are not well qualified to manage the relationships with disabled people, a finding which is consistent with other studies [38,47-49]. The examples highlighted only the situation of the bus drivers from Brasov, Romania, which don't help people with disabilities or the accompanying people, and they confirm the results of a prior study, that driver attitudes is a concern for these people [42]. One of the participants compared the situation in Romania with that from other European Union states, where the bus drivers get off the bus to help people to get in. The participants consider that in Romania, the bus drivers should be trained in order to know what the special needs of this people are and to help them get in the transportation means safely, which might be a problem both of attitude and also a problem of knowing of their needs, as other studies reveal [42].

(2) Identifying the main physical barriers that make the participation in touristic activities harder for persons with disabilities.

The sample members consider that in Romania the legislation regarding the physical access of people with disabilities in public institutions was harmonized with international standards. However, there are a lot of situations when the solutions found by public institutions or by the tourism units didn't solve the access problems, but instead only created an infrastructure that apparently respects the legal provisions. The research participants stressed examples of situations when even though there is infrastructure for a wheelchair, it is still impossible to use it. This types of results were also identified by other studies $[29,34,37,45]$.

Trying to explain that regulations haven't any value if they are not respected, one of the participants noticed a situation of the parking places for people with disabilities where even though they are marked in a visible way, most of the time they are used by people that have no right to do that. "The parking for people with disabilities is also used by other people without any consequences from the authorities"(\#10).

In terms of accommodation infrastructure, in accordance with prior studies [29,35,37], the participants consider that in Romania there are hotel chains that have arranged access ramps, rooms, and bathrooms for people with disabilities, in order to remove physical barriers, but most of the time the tariffs exceed the financial limits of families with disabled children. Just a few of the hotels with low prices can provide optimal conditions of access and accommodation for these families. In the participants' opinions, the most delicate issue is the possibility of providing easy access for people with disabilities to tourist attraction for children. A mother of a child with multiple diseases revealed a situation when she had a vacation organized for families with disabled children at the seaside. Even though the hotel provided proper conditions for the group, access to the beach was almost impossible, because accessibility was assured by a path of $500 \mathrm{~m}$ with no conditions for a proper movement. As a result, most of the families spent their holiday in the hotel.

To prevent difficulties during tourism travel, families with children with disabilities plan all aspects of the trip in detail. The most requested includes the nature of disabled access, the parking possibilities, as well as the room's type, size, equipment, and location. All the parents said that they prefer rooms located at the ground floor to get easy and safe access for their children. Also, they look for information about the safety and the accessibility of the tourism attractions: "I am looking for safe beaches, without stones, where water is smooth. I always check the beach along with other moms" said one of the interviewed mothers (\#21). The necessity of a better communication process was revealed in prior studies [49-51,76].

(3) Identifying some ideas regarding possibilities of diminishing the attitude barriers for the families with disabled children. 
The sample members considered that the society degree of civilization is reflected in the way that it treats those who have special needs; the process of inclusion depends both on the mentality of those in difficulty and on the others. Thus, negative mentalities and attitude might change through the provision of information.

When they were asked if they believe that others should know certain things to accept people with disabilities, the respondents provided an impressive number of ideas that might be grouped into three categories: rational appeals, emotional appeals, and human rights related appeals. Some of the respondents consider that the rational arguments should be appealed to, considering the fact that people should understand that not having a problem in the present doesn't guarantee the same situation in the future, as follows: "A typical child might become a child with special needs at any time" (\#4). "Could you dream the sea without seeing it, feeling it, hearing it?" (\#10) "In any moment, anybody could become a person with special needs, as a result of an accident. How would you like to be treated if you become a different person?" (\#16). The emotional appeals were focused especially on compassion: "Behave as you'd like others to behave with you" (\#11), "Try to understand their needs" (\#9). The third category expresses the idea of equality, by stressing the fact that every person is valuable in a way "Let's learn that every person has something to show and that we can learn something from everybody" (\#5), "It's not a mistake to be different. We all are different" (\#13).

All the participants consider that other people should understand the problems faced by families with disabled children and agreed that through education the situation could change for the better. This idea was highlighted previously in other research [47].

During the research, one of the participants - a mother of a child with Down syndrome -explained the way she succeeded to solve her son's school's integration problems through an emotional appeal addressed to the other parents. During a meeting she explained them all the problems her family is facing with-the special needs of her son, the sacrifices that all the family faces every day, and the need for compassion and respect that they feel. The parents explained their children this particular situation, so the children's attitude changed. After hearing this story, the parents from the interview groups suggested that the tourists' attitudes could be positively changed in a similar way (through education and communication).

From the participants 'perspective, the most desirable way in which the large public could find information about the special needs of some people (including children) is to involve all the people in common activities, so the beneficial effects of interpersonal relationship were revealed $[30,76]$. Also, the classic methods of publicity and information were mentioned, but these ones are considered to be less efficient.

(4) Finding opportunities to use virtual reality (VR) in order to help families with disabled children to identify and to avoid physical barriers in tourism activities

After experiencing the use of VR, all the participants suggested that this technology is able to help families with disabled children through providing better information before planning their journeys. These ideas are consistent with the results of other studies from literature [57-60,64].

All the respondents mentioned that they plan their travels by using the Internet (Google maps, touristic forums, sites). One of the specialists declared that several times advised the parents to show to the children images with the places where they want to go to, so the children get acquainted with the new locations. All the specialists agreed that VR could offer more accurate (visual) details about the locations, confirming the results obtained from the group of parents. "Such a platform benefits these people and their families, because it offers accurate data about a location" (\#8).

Several possibilities to use this technology in the benefit of children with special needs were identified: simulation of travel by car, train or airplane in order to accustom them with the sensations from these transportation means and with the crowd before getting in them; familiarization with tourist destination before arriving, so children to be able to reduce the stress caused by unknown situations. From the respondents' perspective, the most needed information about accommodation that might be tested by using VR are: ways to access the accommodation, the accommodation conditions, access 
to the bathroom, and access to the different touristic objectives. All the participants considered that accommodation that offers the possibility of testing the conditions through VR is preferable to another that doesn't offer this possibility.

All the specialists declared that if they think about organizing a trip for children with disabilities, they could use VR to help with this. Regarding the use of VR by children, most of the specialists appreciate that VR facilitates knowledge and through sensitive stimulation offers an environment that can avoid some phobias. Also, interviewed parents stated that they would use VR to plan a trip. The only person who didn't appreciate this technology was an old aged person, who said that they are not accustomed to modern technology.

\section{Conclusions and Proposals}

The results reveal that the needs of people with disabilities are very complex, as has been noticed in past research [77] and even now these needs are not being debated enough. The above-mentioned results helped us to find answers to the research questions. As the answer to the first research question (Q1) -which is related to first and second research objectives-the attendants of children with disabilities mentioned all the barriers stressed in the literature: attitude barriers, physical barriers, and lack of communication [34].

The main conclusion of the study is that in Romania, authorities, tourists, and employees are not well prepared enough to include atypical tourists like disabled children and their families in tourism activities. Compared to the results of prior studies mentioned during the analysis, this research revealed that in Romania, the participation of the families with disabled children to tourism activities is reduced and the main causes are considered to be cultural factors and economic factors (the family income is usually low). In Romania, attitudinal barriers are strong and they come both from people with disabilities (mentality, a child with disabilities represents, even now, a shame for a lot of families) and from the society, which is not well prepared, educated, or empathetic.

In regards to physical barriers, the results reveal that although accessibility was improved, the sample members considered that these barriers are still present for disabled people.

Related to the second research question (Q2 which is related to the third research objective) the authors concluded that a real change in mentality towards people with disabilities can be done only through education. In this respect, the inclusion of topics related to improving the attitudes towards disabled people in the primary school curriculum could be an incentive for achieving the UN's sustainable development goals [2].

VR technology (approached in Q3 related to the fourth research objectives) could fill the gap between the perceptions about a tourist destination before visit and the real experience in this destination. VR can help children and parents to immerse themselves in the destination, to find facilities and obstacles, and to obtain a better image of the places that they are going to visit.

By taking into consideration the fact that people with disabilities are feeling tourism experiences as well, abolishing the physical and attitude barriers represents a challenge for all stakeholders. Considering the study results, the authors concluded the existence of a lack of communication with these people that causes significant difficulties when trying to avoid the specified barriers. They don't feel like having support in taking the decision to purchase a tourism product. In this context, using VR could facilitate the decisional process, by offering a way to experience some tourism products before traveling.

Starting from these conclusions, the authors have several proposals that could also be applied in other countries with similar contexts. For a better understanding of the results and to increase the ways of using the research conclusions, the authors structured the proposals into 3 categories: proposals for the authorities, proposals for academia, and proposals for the economic environment.

In the authors' opinion, the authorities should design a tourism development strategy which offers advantages for the medium and long term to tourism operators that assure proper facilities for families with disabled children. Related to stakeholders in tourism, a national strategy would stimulate 
their interest for developing such a niche market, with the possibility of gaining significant competitive advantages in the medium and long term. A national strategy can determine an increasing of incomes for national and local authorities coming from stakeholders in tourism, and a better image in society as a consequence of the social responsibility politics generated by such a strategy. The authorities might also become involved in financing specific training programs to prepare tourism employees to work with people with disabilities.

According to the authors, academia, through the advantages offered by the possibility of research conducted in teams that include specialists from different domains, can carry out studies to identify the most viable solutions for the integration of families with disabled children in tourism activities. These studies should be based on the real needs of people with disabilities, because people are different, they have different needs, and integration involves accepting diversity. In these research, virtual reality could be used in order to simulate specific situations of tourism activity (transport, accommodation, crowded places).

The economic environment can be involved in two ways. On the one hand, this can involve financial and logistical support of social responsibility campaigns that are meant to improve their image. On the other hand, this can involve direct investment in tourism units to create facilities specific to families with children with disabilities. Thus, a better access of disabled people to important services, including tourism, can be assured as it is also underlined in literature [79]. These investments could become effective by expanding the target market, because families with disabled children will access services which meet their needs.

In the future, the authors intend to go further in exploring deeper research regarding the needs of disabled children and also regarding the ways that new technologies such as virtual reality and Augmented Reality could help families with disabled children to obtain better and easier participation in tourism activities.

The main limit of the qualitative research is the impossibility of extending the results. At the same time, because only the parents and specialists perspective were focused on, the future research direction has to identify the perspective of the other categories of stakeholders, such as typical tourists, employers, and tourism employees, central, and local authorities, etc.

Author Contributions: All the authors equally contributed to this work, to the research design and analysis. Conceptualization A.S.T., G.B., C.P.C. \& D.F.; resources I.B.C., B.T. \& D.F.; methodology A.S.T., C.P.C. \& G.B.; writing, review, and editing, I.B.C., A.S.T., B.T. \& C.P.C.; supervision, A.S.T. \& G.B. All authors read and approved the final manuscript.

Funding: The research was financed by Transilvania University of Brașov.

Acknowledgments: This article was supported by the Transylvania University of Brasov, Romania, under "Grants for Young Researchers"-2017 competition.

Conflicts of Interest: The authors declare no conflict of interest.

\section{References}

1. Responsible Tourism Partnership. What Is Responsible Tourism? Available online: http:// responsibletourismpartnership.org/ (accessed on 7 February 2018).

2. UNWTO. The Tourism Sector and the Sustainable Development Goals—Responsible Tourism, a Global Commitment. 2016. Available online: http://cf.cdn.unwto.org/sites/all/files/pdf/turismo_responsable_omt_ acc.pdf (accessed on 15 February 2018).

3. Kastenholz, E.; Eusébio, C.; Figueiredo, E. Contributions of tourism to social inclusion of persons with disability. Disabil. Soc. 2015, 30, 1259-1281. [CrossRef]

4. Lehto, X.; Luo, W.; Miao, L.; Ghiselli, R.F. Shared tourism experience of individuals with disabilities and their caregivers. J. Destin. Mark. Manag. 2018, 8, 185-193. [CrossRef]

5. WHO. Disability and Health. Key Facts. Available online: http://www.who.int/en/news-room/fact-sheets/ detail/disability-and-health (accessed on 7 September 2018). 
6. Global Partnership for Education. Available online: https://www.globalpartnership.org/focus-areas/childrenwith-disabilities (accessed on 11 September 2018).

7. Yau, M.K.; McKercher, B.; Packer, T.L. Traveling with a disability: More than an Access Issue. Ann. Tour. Res. 2004, 31, 946-960. [CrossRef]

8. Mactavish, J.B.; Mackay, K.J.; Iwasaki, Y.; Betteridge, D. Family Caregivers of Individuals with Intellectual Disability: Perspectives on Life Quality and the Role of Vacations. J. Leis. Res. 2007, 39, 127-155. [CrossRef]

9. Scheyvens, R.; Biddulph, R. Inclusive tourism development. Tour. Geogr. 2018, 20, 589-609. [CrossRef]

10. Tchetchik, A.; Eichhorn, V.; Biran, A. 'Not on my vacation': Service encounters between able-bodied and disabled consumers-The case of high-contact service. J. Policy Res. Tour. Leis. Events 2018, 10, 204-220. [CrossRef]

11. National Authority for Persons with Disabilities. Quarterly Statistics. Available online: http://anpd.gov.ro/ web/transparenta/statistici/trimestriale/ (accessed on 12 September 2018).

12. Mathew, P.V.; Sreejesh, S. Impact of responsible tourism on destination sustainability and quality of life of community in tourism destinations. J. Hosp. Tour. Manag. 2017, 31, 83-89. [CrossRef]

13. Hanafiah, M.H.; Azman, I.; Jamaluddin, M.R.; Aminuddin, N. Responsible Tourism Practices and Quality of Life: Perspective of Langkawi Island communities. Procedia-Soc. Behav. Sci. 2016, 222, 406-413. [CrossRef]

14. Lee, H.Y.; Bonn, M.A.; Reid, E.L.; Kim, W.G. Differences in tourist ethical judgment and responsible tourism intention: An ethical scenario approach. Tour. Manag. 2017, 60, 298-307. [CrossRef]

15. Yoon, A.; Jeong, D.; Chon, J.; Yoon, J.H. A Study of Consumers' Intentions to Participate in Responsible Tourism Using Message Framing and Appeals. Sustainability-Basel 2019, 11, 865. [CrossRef]

16. Musavengane, R. Small hotels and responsible tourism practice: Hoteliers' perspectives. J. Clean. Prod. 2019, 220, 786-799. [CrossRef]

17. Camilleri, M.A. Responsible tourism that creates shared value among stakeholders. Tour. Plan. Dev. 2016, 13, 219-235. [CrossRef]

18. Rojan, B.; Brijesh, T.; Min-Seong, K. Corporate Social Responsibility Among Travel and Tour Operators in Nepal. Sustainability-Basel 2019, 11, 2771. [CrossRef]

19. Byrd, E.T. Stakeholders in sustainable tourism development and their roles: Applying stakeholder theory to sustainable tourism development. Tour. Rev. 2007, 62, 6-13. [CrossRef]

20. WTO. Survey on the Implementation of the Global Code of Ethics for Tourism, Paragraph 32. 2005. Available online: http://www.safecoastaltourism.org/article/stakeholders-tourism-development-according-unwto) (accessed on 7 September 2018).

21. Michopoulou, E.; Darcy, S.; Ambrose, I.; Buhalis, D. Accessible tourism futures: The world we dream to live in and the opportunities we hope to have. J. Tour. Futures 2015, 1, 179-188. [CrossRef]

22. Alegre, I.; Berbegal-Mirabent, J. Social innovation success factors: Hospitality and tourism social enterprises. Int. J. Contemp. Hosp. Manag. 2016, 28, 1155-1176. [CrossRef]

23. Loi, K.L.; Kong, W.H. Tourism for All: Challenges and Issues Faced by People with Vision Impairment. Tour. Plan. Dev. 2017, 14, 181-197. [CrossRef]

24. Shams, R. Stakeholder Causal Scope to Bridge the Industry-Academia Collaboration Gap. 2018. Available online: https:/www.emeraldpublishing.com/news-and-blogs/stakeholder-causal-scope-to-bridgethe-industry-academia-collaboration-gap (accessed on 5 September 2018).

25. Sarmento, E.M.; Brás, C.; De Oliveira, C.V. Issues and challenges of accessibility for senior tourism (Estoril/Portugal). R-LEGO—Revista Lusófona de Economia e Gestão das Organizações. 2016, Volume 2. Available online: http://recil.grupolusofona.pt/handle/10437/6978 (accessed on 7 June 2019).

26. Pagán, R. The contribution of holiday trips to life satisfaction: The case of people with disabilities. Curr. Issues Tour. 2015, 18, 524-538. [CrossRef]

27. Zenko, Z.; Sardi, V. Systemic thinking for socially responsible innovations in social tourism for people with disabilities. Kybernetes 2014, 43, 652-666. [CrossRef]

28. Olya, H.G.T.; Gazi, Z.A.; Aksal, F.A.; Mehmet, A. Behavioral intentions of disabled tourists for the use of peer-to-peer accommodations: An application of fsQCA. Int. J. Contemp. Hosp. Manag. 2018, 30, 436-454. [CrossRef]

29. Nyman, E.; Westin, K.; Carson, D. Tourism destination choice sets for families with wheelchair-bound children. Tour. Recreat. Res. 2018, 43, 26-38. [CrossRef] 
30. Kong, W.H.; Loi, K.I. The barriers to holiday-taking for visually impaired tourists and their families. J. Hosp. Tour. Manag. 2017, 32, 99-107. [CrossRef]

31. Sedgley, D.; Pritchard, A.; Morgan, N.; Hanna, P. Tourism and autism: Journeys of mixed emotions. Ann. Tour. Res. 2017, 66, 14-25. [CrossRef]

32. Bergier, B.; Bergier, J.; Kubinska, Z. Environmental Determinants of Participation in Tourism and Recreation of People Withvarying Degrees of Disability. J. Toxicol. Environ. Health Part A 2010, 73, 1134-1140. [CrossRef] [PubMed]

33. Pagan, R. How important are holiday trips in preventing loneliness? Evidence for people without and with self-reported moderate and severe disabilities. Curr. Issues Tour. 2019. [CrossRef]

34. Eichhorn, V.; Buhalis, D. Accesibility a Key Objectives for the Tourism Industrie. In Accessible Tourism: Concepts and Issues; Buhalis, D., Darcy, S., Eds.; Channel View Publication: Bristol, UK, 2011; p. 50.

35. Tutuncu, O. Investigating the accessibility factors affecting hotel satisfaction of people with physical disabilities. Int. J. Contemp. Hosp. Manag. 2017, 65, 29-36. [CrossRef]

36. Lyu, S.O. Which accessible travel products are people with disabilities willing to pay more? A choice experiment. Tour. Manag. 2017, 59, 404-412. [CrossRef]

37. Poria, Y.; Reichel, A.; Brandt, Y. Dimensions of hotel experience of people with disabilities: An exploratory study. Int. J. Contemp. Hosp. Manag. 2011, 23, 571-591. [CrossRef]

38. Ferrari, L.; Berlingerio, M.; Calabrese, F.; Reades, J. Improving the accessibility of urban transportation networks for people with disabilities. Transp. Res. Part C Technol. 2014, 45, 27-40. [CrossRef]

39. Risser, R.; Månsson Lexell, E.; Bell, D.; Iwarsson, S.; Ståhl, A. Use of local public transport among people with cognitive impairments-A literature review. Transp. Res. Part F Traffic Psychol. Behav. 2015, 29, 83-97. [CrossRef]

40. Zajac, A.P. City accessible for everyone-Improving accessibility of public transport using the universal design concept. In Proceedings of the 6th Transport Research Arena, Warsaw, Poland, 18-21 April 2016; Available online: https://core.ac.uk/download/pdf/82721015.pdf (accessed on 7 September 2018).

41. Karacaoglu, S.; Yolal, M.; Gursoy, D. Examining the Perceptions of Mobility-Impaired Travelers: An Analysis of Service Expectations, Evaluations, and Travel Barriers. Tour. Rev. Int. 2015, 19, 19-30. [CrossRef]

42. Park, J.; Chowdhury, S. Investigating the barriers in a typical journey by public transport users with disabilities. J. Transp. Health. 2018, 10, 361-368. [CrossRef]

43. Darcy, S. Flying with Impairments: Improving Airline Practices by Understanding the Experiences of People with Disabilities. Tourism Travel and Research Association: Advancing Tourism Research Globally. 2016, p. 47. Available online: http://scholarworks.umass.edu/ttra/2007/Presented_Papers/47 (accessed on 7 September 2018).

44. Wang, W.; Cole, S.A. Constant Comparative Analysis to Identify Onboard Service Needs and Expectations of Air Travelers with Mobility Impairments: Perceptions of Flight Attendants. Tourism Travel and Research Association: Advancing Tourism Research Globally: Amherst, MA, USA, 2016; Available online: http://scholarworks.umass.edu/ttra/2012/Oral/33 (accessed on 7 September 2018).

45. Cole, S.; Hoback, N.; Whiteneck, G. Travel Service Gaps for Wheelchair Users. Tourism Travel and Research Association: Advancing Tourism Research Globally: Amherst, MA, USA, 2016; Available online: http://scholarworks.umass.edu/ttra/2016/Qualitative_Research_Workshop/11 (accessed on 7 September 2018).

46. Poria, Y.; Reichel, A.; Brandt, Y. People with disabilities visit art museums: An exploratory study of obstacles and difficulties. J. Herit. Tour. 2009, 4, 117-129. [CrossRef]

47. Bizjak, B.; Knežević, M.; Cvetrežnik, S. Attitude change towards guests with disabilities: Reflections From Tourism Students. Ann. Tour. Res. 2011, 38, 842-857. [CrossRef]

48. Kim, W.G.; Stonesifer, H.W.; Han, J.S. Accommodating the needs of disabled hotel guests: Implications for guests and management. Int. J. Hosp. Manag. 2012, 31, 1311-1317. [CrossRef]

49. Cloquet, I.; Palomino, M.; Shaw, G.; Stephen, G.; Taylor, T. Disability, social inclusion and the marketing of tourist attractions. J. Sustain. Tour. 2018, 26, 221-237. [CrossRef]

50. Rumetshofer, H.; Wöß, W. Tourism Information Systems Promoting Barrier-Free Tourism for People with Disabilities. In Computers Helping People with Special Needs. ICCHP 2004. Lecture Notes in Computer Science; Miesenberger, K., Klaus, J., Zagler, W.L., Burger, D., Eds.; Springer: Berlin/Heidelberg, Germany, 2004; Volume 3118. 
51. Vila, T.D.; González, E.A.; Darcy, S. Accessible tourism online resources: A Northern European perspective. Scand. J. Hosp. Tour. 2018, 19, 140-156. [CrossRef]

52. Foley, A.; Ferri, B.A. Technology for people, not disabilities: Ensuring access and inclusion. JORSEN 2012, 12, 192-200. [CrossRef]

53. Gea, M.; Alaman, X.; Rodriguez, P.; Martinez, V. Towards Smart \& Inclusive Society: Building 3d Immersive Museum By Children With Cognitive Disabilities. In Proceedings of the EDULEARN16: 8th International Conference on Education and New Learning Technologies, Barcelona, Spain, 4-6 July 2016; Chova, L.G., Martinez, A.L., Torres, I.C., Eds.; EDULEARN Proceedings: Barcelona, Spain, 2016; pp. 5260-5268.

54. Coxon, M.; Kelly, N.; Page, S. Individual Differences in Virtual reality: Are Spatial Presence and Spatial Ability Linked? Virtual Real. 2016, 20, 203-212. [CrossRef]

55. Nayyar, A.; Mahapatra, B.; Le, D.; și Suseendran, G. Virtual reality (VR) \& Augmented Reality (AR) technologies for tourism and hospitality industry. Int. J. Eng. Technol. 2018, 7, 156-160.

56. Barnes, S. Understanding Virtual reality in Marketing: Nature, Implications and Potential. SSRN Electron. J 2016, 25. [CrossRef]

57. Standen, P.J.; Brown, D.J. Virtual reality in the Rehabilitation of People with Intellectual Disabilities: Review. Cyberpsychol. Behav. 2005, 8, 272-282. [CrossRef]

58. Parsons, S.; Cobb, S. State-of-the-art of virtual reality technologies for children on the autism spectrum. Eur. J. Spec. Needs Educ. 2011, 26, 355-366. [CrossRef]

59. Lorenzo, G.; Lledó, A.; Pomares, J.; Roig, R. Design and application of an immersive virtual reality system to enhance emotional skills for children with autism spectrum disorders. Comput. Educ. 2016, 98, 192-205. [CrossRef]

60. Didehbani, N.; Allen, T.; Kandalaft, M.; Chapman, S. Virtual reality Social Cognition Training for children with high functioning autism. Comput. Hum. Behav. 2016, 62, 703-711. [CrossRef]

61. Tussyadiah, I.P.; Wang, D.; Jung, T.H.; Dieck, M.C.T. Virtual reality, presence, and attitude change: Empirical evidence from tourism. Tour. Manag. 2018, 66, 140-154. [CrossRef]

62. Gibson, A.; O'Rawe, M. Virtual reality as a Travel Promotional Tool: Insights from a Consumer Travel Fair. In Augmented Reality and Virtual reality. Progress in IS; Jung, T., Tom Dieck, M., Eds.; Springer International Publishing: London, UK, 2018.

63. Tussyadiah, I.P.; Wang, D.; Jia, C. Virtual reality and Attitudes Toward Tourism Destinations. In Information and Communication Technologies in Tourism; Schegg, R., Stangl, B., Eds.; Springer: Cham, Switzerland, 2017.

64. Bogicevic, V.; Seo, S.; Kandampully, J.A.; Liu, S.Q.; Rudd, N.A. Virtual reality presence as a preamble of tourism experience: The role of mental imagery. Tour. Manag. 2019, 74, 55-64. [CrossRef]

65. Han, D.I.D.; Dieck, M.C.T. Calling for user-centric VR design research in hospitality and tourism. Hosp. Soc. 2019, 9, 237-246. [CrossRef]

66. Malhotra, N.K. Marketing Research. An Aplied Orientation; Pearson Education International: Upper Saddle River, NJ, USA, 2004; p. 146.

67. Fern, E.F. Advanced Focus Group Research; Sage Publications: London, UK, 2001; p. 181.

68. Guest, G.; Namey, E.; McKenna, K. How Many Focus Groups Are Enough? Building an Evidence Base forNonprobability Sample Sizes. Field Methods 2017, 29, 3-22. [CrossRef]

69. Liamputtong, P. Focus Group Methodology: Principle and Practice; Sage Publications: Thousand Oaks, CA, USA, 2011 ; p. 25.

70. Stewart, D.W.; Shamdasani, P.N. Focus Groups: Theory and Practice; Sage Publications: Thousand Oaks, CA, USA, 2014; p. 124.

71. Rabiee, F. Focus-group interview and data analysis. Proc. Nutr. Soc. 2004, 63, 655-660. [CrossRef]

72. Nili, A.; Tate, M.; Johnstone, D. A framework and approach for analysis of focus group data in information systems research. Commun. Assoc. Inf. Syst. 2017, 40, 1-21. [CrossRef]

73. Onwuegbuzie, A.J.; Dickinson, W.B.; Leech, N.L.; Zoran, A.G. A Qualitative Framework for Collecting and Analyzing Data in Focus Group Research. Int. J. Qual. Methods 2009, 8, 1-21. [CrossRef]

74. Knoesen, B.C.; Goliath, V.; Soji, Z.; Steenkamp, L.; Truter, I. Recording of nonverbal communication during focus group discussions in health research. Afr. J. Phys. Act. Health Sci. 2017, 23.

75. Decrop, A. Triangulation in qualitative tourism research. Tour. Manag. 1999, 20, 157-161. [CrossRef] 
76. Broach, S.; Clements, L.; Read, J. Disable Children: A Legal Handbook, 2nd ed.; Council for Disabled children: London, UK, 2016; Available online: https://councilfordisabledchildren.org.uk/help-resources/resources/ disabled-children-legal-handbook-2nd-edition (accessed on 1 July 2019).

77. Shelton, E.J.; Tucker, H. Tourism and disability: Issues beyond access. Tour. Rev. Int. 2005, 8, $211-219$. [CrossRef]

78. Shaw, G.; Coles, T. Disability, holiday making and the tourism industry in the UK: A preliminary survey. Tour. Manag. 2004, 25, 397-403. [CrossRef]

79. Wolbring, G.; Rybchinski, T. Social Sustainability and Its Indicators through a Disability Studies and an Ability Studies Lens. Sustainability-Basel 2013, 5, 4889-4907. [CrossRef]

(C) 2019 by the authors. Licensee MDPI, Basel, Switzerland. This article is an open access article distributed under the terms and conditions of the Creative Commons Attribution (CC BY) license (http://creativecommons.org/licenses/by/4.0/). 